\title{
ARTICLE OPEN \\ Removal of Cr (III) and Ni (II) from tannery effluent using calcium carbonate coated bacterial magnetosomes
}

\author{
Jobin John Jacob ${ }^{1}$, R. Varalakshmi ${ }^{1}$, S. Gargi ${ }^{1}$, M. A. Jayasri ${ }^{1}$ and K. Suthindhiran ${ }^{1}$
}

\begin{abstract}
Heavy metal contamination of surface water bodies and ground water has been a major problem around the world. Calcium-based adsorbents are effective but cannot be separated easily after the treatment. Magnetosomes are biogenic magnetite synthesised as highly ordered chain-like structures by magnetotactic bacteria. In this study, we have prepared magnetically controlled calcite microcrystals using magnetosomes for the adsorption experiment. The ability of magnetic calcite as adsorbent was investigated for the removal of $\mathrm{Cr}$ (III) and $\mathrm{Ni}$ (II) ions from synthetic solution. Critical parameters, such as the effect of pH, temperature, contact time, initial ion concentration, and adsorbent dose, were optimised in comparison with calcite, magnetosomes, and activated carbon for maximum metal ion removal. The study showed that equilibrium was established in $1 \mathrm{~h}$ for both $\mathrm{Cr}$ (III) and $\mathrm{Ni}$ (II) at a pH of 6.0 and 8.0, respectively. The adsorption process follows pseudo-second-order reaction kinetics, along with Langmuir and Freundlich adsorption isotherms. The thermodynamics of adsorption of both metal ions on magnetic calcite showed that the adsorption was spontaneous and endothermic in nature. Magnetically controlled calcite crystals successfully removed $\mathrm{Cr}$ (III) and Ni (II) from collected tannery effluent and separated from the solution by applying magnetic field. Maximum removal of chromium and nickel ( 94 and $84 \%$ ) by magnetic calcite is similar to calcite crystals but higher than magnetosomes and activated carbon. The results indicated that magnetic calcite could be used as an alternative adsorbent for removing heavy metals from tannery effluent.
\end{abstract}

npj Clean Water (2018)1:1 ; doi:10.1038/s41545-018-0001-2

\section{INTRODUCTION}

Heavy metal contamination is a cause of serious concern for the environment, aquatic life, animals and humans. ${ }^{1}$ The unplanned industrialisation and urbanisation caused severe threat to water bodies worldwide. ${ }^{2}$ In developing countries, the industries are located along the water bodies, and it discharges untreated toxic waste to the surface water. ${ }^{3}$ The presence of heavy metal ions in water bodies has been a major concern as it can induce toxicity at low-level exposure. The sources of heavy metals in the water bodies are anthropogenic activities, industrial, agricultural, domestic effluents and natural sources. ${ }^{4}$

The tanning industry that occupies a place of prominence in developing countries produce large amount of wastewater containing toxic heavy metals $(\mathrm{Cr}, \mathrm{Pb}, \mathrm{Zn}, \mathrm{Cu}, \mathrm{Cd}, \mathrm{As}, \mathrm{Se})^{5}$ Discharge of untreated effluents into the waterbodies causes surface and ground water pollution, endangering biodiversity and lowering agriculture production. ${ }^{6}$ Some of the heavy metals are toxic, carcinogenic or mutagenic, even in very low concentrations. For example, chromium alum and chromium (III) sulphate used during the tanning process produce two forms of chrome; hexavalent chromium and trivalent chromium in which the hexavalent form is toxic. ${ }^{7}$ Heavy metals tend to bio-accumulate in the human body and increase the concentration of a chemical in biological organism overtime. A recent report by Roy et al. showed heavy metals present in tannery effluent are toxic to microorganisms, algae, plants and red blood cells (RBC). ${ }^{8}$

Treatment of metal-contaminated wastewater prior to its discharge to the environment is crucial for the reduction of toxicity. Conventional treatment processes for heavy metal removal from wastewater include chemical precipitation, preoxidation or post-oxidation, coagulation, activated carbon adsorption, reduction, ion exchanges, etc. ${ }^{9}$ These processes have many drawbacks, such as high inputs, toxic by-products and incomplete metal removal. Over the last few decades, cheaper and more effective technologies have been developed for the removal of low levels of trace metals from wastewater and water supplies. ${ }^{10}$ Calcium carbonate is an economically efficient and eco-friendly adsorbent for the removal of heavy metals from water. $\mathrm{CaCO}_{3}$ has been used to remove manganese, ${ }^{11}$ cadmium, lead, zinc, nickel and chromium. ${ }^{12}$ However, the serious problem of treating metalcontaminated water using calcium carbonate was the drop in the quality of water after treatment. ${ }^{13}$

The difficulty in separating calcium carbonate from the treated water can be resolved by a secondary separation based on a magnetically enhanced separation technology. ${ }^{14}$ Magnetic nanoparticles (MNPs)-based adsorbents are widely used in bioremediation due to the large surface area and easy separation by an external magnetic field. ${ }^{15}$ However, the toxicity of chemically synthesised MNPs hindered further development of MNPs-based heavy metal removal filters. ${ }^{16}$ Magnetosomes extracted from magnetotactic bacteria (MTB) could be a feasible alternative to resolve such problems. Magnetosomes mineral consists of single crystals of either the ferrimagnetic iron oxide, magnetite $\left(\mathrm{Fe}_{3} \mathrm{O}_{4}\right)$, or the iron sulphide, greigite $\left(\mathrm{Fe}_{3} \mathrm{~S}_{4}\right)$ enveloped by a bilayer lipid membrane. ${ }^{17}$ Magnetic properties of MTB have been a subject of growing interest in recent years due to a high level of

\footnotetext{
${ }^{1}$ Marine Biotechnology and Bioproducts Lab, School of Biosciences and Technology, VIT University, Vellore, India

Correspondence: K. Suthindhiran (ksuthindhiran@vit.ac.in)
}

Received: 1 September 2016 Revised: 15 August 2017 Accepted: 22 September 2017

Published online: 26 April 2018 
biocompatibility, low toxicity, narrow size distribution and excellent dispersion. In this study, we have fabricated calcium carbonate coated magnetosomes and critical adsorption parameters have been analysed. The possibilities of using magnetically responsive calcium carbonate microcrystals as an alternative method for the removal of heavy metals (Cr (III), Ni (II)) from tannery effluent have been studied briefly.

\section{RESULTS AND DISCUSSION}

Characterisation of magnetosomes, calcite and calcite coated magnetosomes

The yield of magnetosomes from Magnetospirillum sp. VITRJS2 was found to be $10 \pm 0.7 \mathrm{mg} / \mathrm{L}$ of bacterial culture. The cultivation yield of magnetosomes was found to be less than the amount obtained elsewhere. ${ }^{18}$ This could be because the hungate standard technique is less efficient than the chemostat culturing method. Modifications of growth media and culturing conditions have

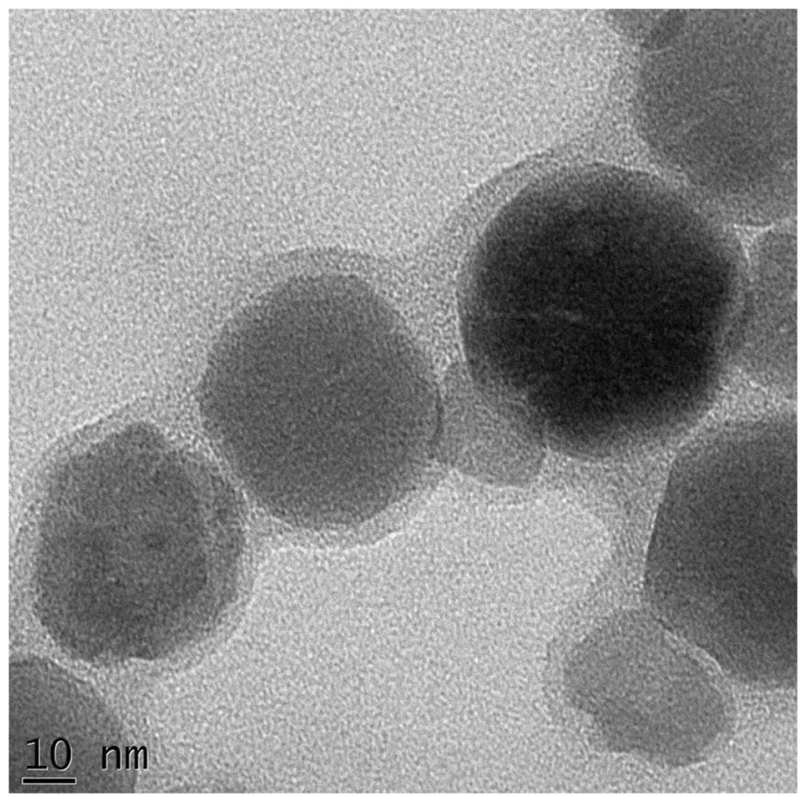

Fig. 1 Transmission electron microscopy (TEM) image of a chain of cubo-octahedral magnetite magnetosomes isolated from the strain VITRJS-2. Individual magnetosome crystals were surrounded by a membrane. The extracted magnetosomes were applied to copper grids and negatively stained with $2.5 \%(\mathrm{w} / \mathrm{v})$ ammonium molybdate yielded overproduction of magnetosomes in which a maximum yield of $83.23 \pm 5.36 \mathrm{mg} / \mathrm{L}$ was obtained. ${ }^{18}$

The shape and size of magnetosomes were determined by transmission electron microscopy (TEM) analysis. The extracted magnetosomes were cubo-octahedral shaped and arranged in chains (Fig. 1). The surface morphology and chemical purity of extracted magnetosome, calcite and calcite-coated magnetosomes were visualised by SEM/EDS analysis (Fig. 2). The synthesised calcite and magnetic calcite showed cubic crystalline structure. EDS analysis of calcite indicated $48.1 \%$ carbon, $39.5 \%$ oxygen and $12.4 \%$ calcium, whereas magnetosome coupled calcite showed $1.6 \%$ iron which confirms the coupling of calcite and magnetosomes. ${ }^{19}$

FTIR analysis of magnetosomes, calcite and magnetic calcite showed the absorption peaks from 500 to $4000 \mathrm{~cm}^{-1}$ (Fig. 3). The presence of $\mathrm{Fe}-\mathrm{O}$ bonds which confirms the magnetite elemental composition of magnetosome. Magnetosomes showed characteristic Fe-O peaks at $524.64 \mathrm{~cm}^{-1}$ (Fig. 3a). ${ }^{20}$ Calcite showed peaks of calcium at the absorption, $700-900 \mathrm{~cm}^{-1} 21$ and bands of carbonate were found at 1082 and $1381 \mathrm{~cm}^{-1}$. The magneticcalcite possesses both magnetite $\left(513 / 487 \mathrm{~cm}^{-1}\right)$ and calcite (709/ $869 \mathrm{~cm}^{-1}$ ) peaks.(Fig. 3c). The presence of peaks from magnetite and calcite represents the coupling of both thus forming magnetic-calcite.

\section{Adsorption of $\mathrm{Cr}$ (III) and $\mathrm{Ni}$ (II) from aqueous solution}

Effect of different factors on adsorption of $\mathrm{Cr}$ (III) and $\mathrm{Ni}$ (II) by magnetosome, activated carbon, calcite and magnetic calcite was optimised through batch experiments. Critical parameters such as the effect of $\mathrm{pH}$, temperature, contact time, initial ion concentration and adsorbent dose were analysed.

Effect of $\mathrm{pH}$ on adsorption of $\mathrm{Cr}$ (III) and $\mathrm{Ni}$ (II) from aqueous solution

The initial $\mathrm{pH}$ of the sorption medium is a critical parameter for adsorption experiments. Change in $\mathrm{pH}$ influences the surface charge and the degree of ionisation of the adsorbent surface and thereby affects the sorption capacity. ${ }^{22}$ Hence the effect of $\mathrm{pH}$ on adsorption of $\mathrm{Cr}$ (III) and $\mathrm{Ni}$ (II) ions were studied in the range of 2.0-8.0 (Fig. 4). Maximum biosorption capacities were attained at $\mathrm{pH} 6.0$ and 8.0 for $\mathrm{Cr}$ (III) and Ni (II), respectively. The amount of $\mathrm{Cr}$ (III) and $\mathrm{Ni}$ (II) adsorbed per unit of adsorbent increased from $\mathrm{pH}$ 2.0 to 6.0 for all four adsorbents. At low pH (2.0) $\mathrm{H}^{+}$ions compete with the metal ions to bind on the adsorbent surface and when the $\mathrm{pH}$ increased the negatively charged adsorbent surface was available for the metal ions. ${ }^{23}$ However, $\mathrm{Cr}$ (III) and $\mathrm{Ni}$ (II) precipitate at $\mathrm{pH}$ values above 8.0 and hinder the adsorption
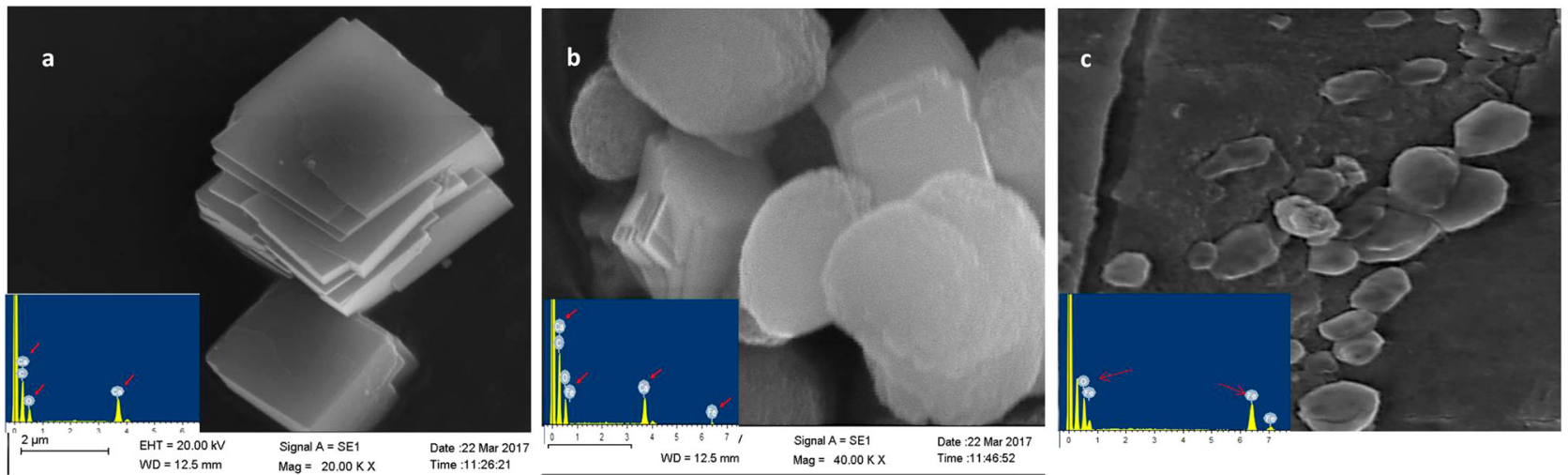
$\begin{array}{lll}E H T=20.00 \mathrm{kV} & \text { Signal } A=S E 1 & \text { Date }: 22 \mathrm{Mar} 2017 \\ W D=12.5 \mathrm{~mm} & \text { Mag }=20.00 \mathrm{KX} & \text { Time :11:26:21 }\end{array}$ Mag $=40.00 \mathrm{KX}$

Fig. 2 SEM/EDS analysis of (a) calcite microcrystals are of typical rhombohedron/cubic. Crystalline structure and EDS analysis of calcite indicated $48.1 \%$ carbon, $39.5 \%$ oxygen and $12.4 \%$ calcium. (b) Magnetic calcite shows the cubic shaped calcite microcrystals and octahedron shaped magnetosome crystals. EDS spectrum of magnetosome coupled calcite showed $1.6 \%$ iron which confirms the coupling of calcite and magnetosomes. (c) Magnetosomes shows the cubo-octahedral shaped nano crystals arranged as chains 


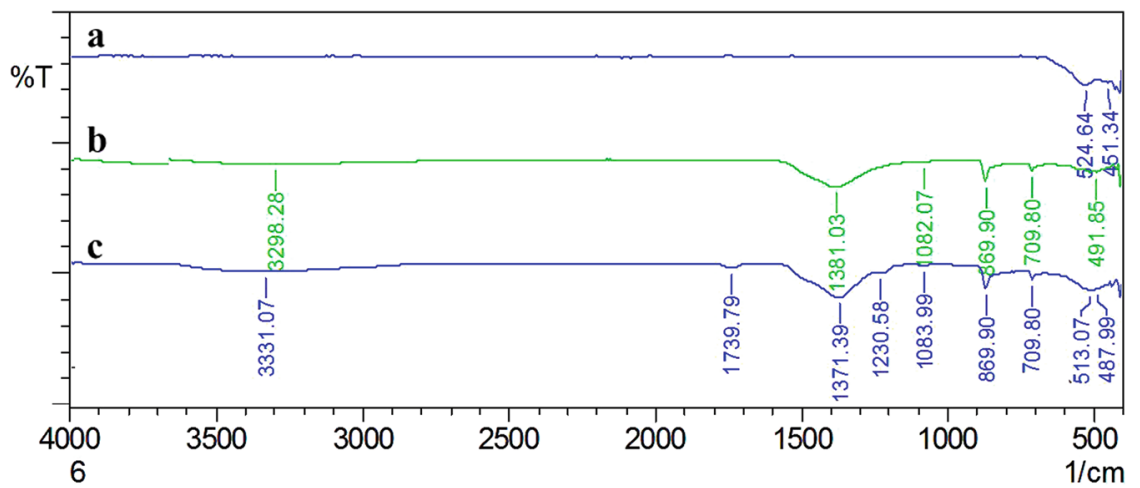

Fig. 3 FTIR analysis of (a) magnetosomes shows characteristic Fe-O peaks at $524.64 \mathrm{~cm}^{-1}$. (b) Calcite shows peaks of calcium at the absorption, $700-900 \mathrm{~cm}^{-1}$ and bands of carbonate were found at 1082 and $1381 \mathrm{~cm}^{-1}$. (c) Magnetic calcite possesses both magnetite (513/ $\left.487 \mathrm{~cm}^{-1}\right)$ and calcite $\left(709 / 869 \mathrm{~cm}^{-1}\right)$ peaks
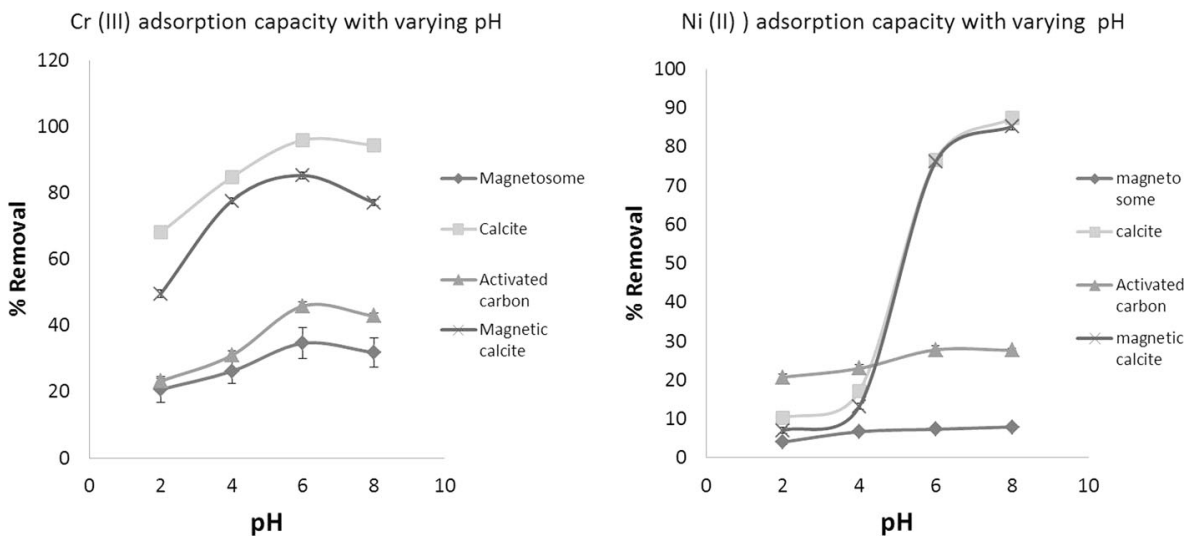

Fig. 4 Effect of $\mathrm{pH}$ on equilibrium $\mathrm{Cr}$ (III) and Ni (II) adsorption capacity of magnetosome, activated carbon, magnetic calcite and activated calcite (biosorbent dose $=0.5 \mathrm{~g} / \mathrm{L} ; C_{0}=10 \mathrm{~g} / \mathrm{L}$; contact time $=12 \mathrm{~h} ; T=30^{\circ} \mathrm{C}$ )

process. Among the four adsorbents used calcite and magnetic calcite showed maximum removal efficiency for $\mathrm{Cr}$ (III) (95 and $85 \%$, respectively) followed by activated carbon (45\%) and magnetosomes (34\%). Adsorption of $\mathrm{Ni}$ (III) followed a similar pattern with maximum removal efficiency of 87 and $85 \%$ by calcite and magnetic calcite.

Effect of temperature on adsorption of $\mathrm{Cr}$ (III) and $\mathrm{Ni}$ (II) from aqueous solution

The adsorption of $\mathrm{Cr}$ (III) and $\mathrm{Ni}$ (II) onto the adsorbents was studied as a function of temperature at different time intervals (Fig. 5). It was observed that the removal of both metals increased with increase in temperature from 20 to $40^{\circ} \mathrm{C}$. Although the rise in $\%$ removal efficiency while increasing the temperature is slight, the highest \% removal efficiency was observed at temperature $40^{\circ} \mathrm{C}$ for both calcite and magnetic calcite. Calcite and magnetic calcite recorded the highest \% removal efficiency of $99 \%$ for $\mathrm{Cr}$ (III) adsorption and $86 \%$ for $\mathrm{Ni}$ (II) adsorption. The adsorption process is endothermic, and availability of more active sites at a higher temperature may be one reason for the increase in adsorption. ${ }^{24}$

Effect of initial metal concentration on adsorption of $\mathrm{Cr}$ (III) and $\mathrm{Ni}$ (II) from aqueous solution

Six different concentrations of $\mathrm{Cr}$ (III) and Ni (II) ions (50, 100, 250, $500,1000,2000 \mathrm{mg} / \mathrm{L}$ ) were used to determine the effect of initial metal concentration on the adsorption capacity of four selected adsorbents at three different temperatures (Fig. 6). At all the measured temperature, the increase in initial metal concentration results in the increase in adsorption capacity. However, the \% removal efficiency (yield) decreased as the sorption sites get saturated by a higher amount of metal ions. At the lower concentration of metal ions, the available sites of adsorption are more hence higher adsorption yield is obtained. ${ }^{25}$

Effect of adsorbent dose on adsorption of $\mathrm{Cr}$ (III) and Ni (II) from aqueous solution

The influence of adsorbent dose on adsorption of $\mathrm{Cr}$ (III) and Ni (II) is shown in Fig. 7. Different doses of adsorbent (100, 250, 500, $1000,2000 \mathrm{mg} / \mathrm{L})$ were used to find the optimum dosage to remove the maximum amount of $\mathrm{Cr}$ (III) and $\mathrm{Ni}$ (II) from aqueous solution. When the adsorbent dosage increased the yield of adsorption increased, but the adsorption capacity declined. The percentage of adsorption increased from 35.5 to $99 \%$ and from 35 to $82 \%$ respectively, for $\mathrm{Cr}$ (III) and $\mathrm{Ni}$ (II) when treated with calcite. $\mathrm{Cr}$ (III) and $\mathrm{Ni}$ (II) ions solution treated with magnetic calcite also followed a similar pattern of adsorption. The adsorption capacity of $\mathrm{Cr}$ (III) and Ni (II) adsorbed decreased from 3355 to $241.39 \mathrm{mg} / \mathrm{g}$ and from 3700 to $423 \mathrm{mg} / \mathrm{g}$, respectively, when calcite/magnetic calcite was used as the adsorbate. The increase in percentage removal could be due to increase in available adsorption sites, whereas the availability of remaining unsaturated sites decreases the adsorption capacity. ${ }^{26}$

Effect of contact time on adsorption of $\mathrm{Cr}$ (III) and $\mathrm{Ni}$ (II) from aqueous solution

The equilibrium point of $\mathrm{Cr}$ (III) and $\mathrm{Ni}$ (II) adsorption from aqueous solution were determined. The adsorption capacity and adsorption yield were calculated at different time intervals to find the 
nPj Removal of $\mathrm{Cr}$ (III) and Ni (II) from tannery
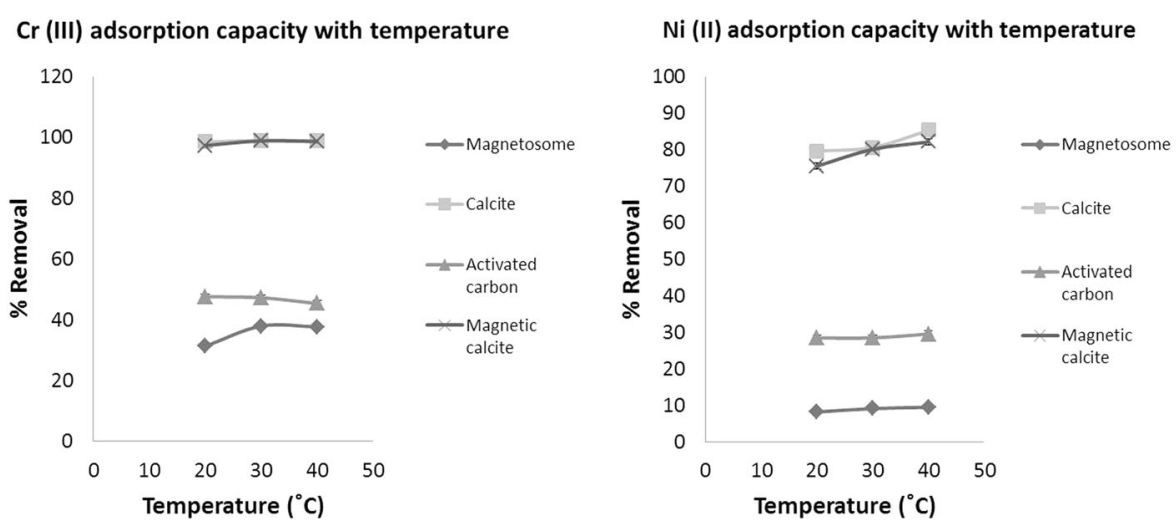

Fig. 5 Effect of temperature on equilibrium $\mathrm{Cr}$ (III) and Ni (II) adsorption capacity of magnetosome, activated carbon, magnetic calcite and activated calcite (biosorbent dose $=0.5 \mathrm{~g} / \mathrm{L} ; C_{0}=10 \mathrm{~g} / \mathrm{L}$; contact time $=12 \mathrm{~h} ; \mathrm{pH}=6.0$ for $\mathrm{Cr}$ (III) and 8.0 for $\mathrm{Ni}$ (II)

$\operatorname{Cr}$ (III) adsorption capacity with initial metal concentration

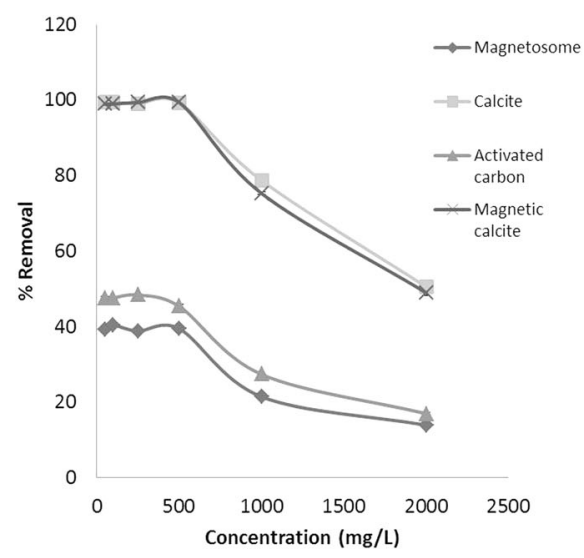

Ni (II) adsorption capacity with initial metal concentration

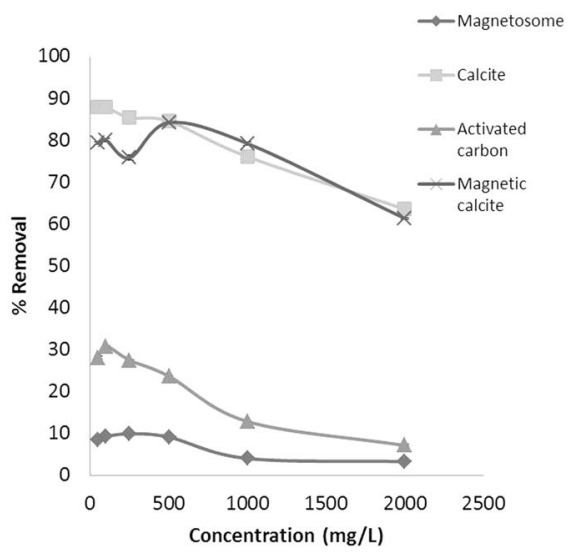

Fig. 6 Effect of initial ion concentration on equilibrium $\mathrm{Cr}$ (III) and $\mathrm{Ni}$ (II) adsorption capacity of magnetosome, activated carbon, magnetic calcite and activated calcite (biosorbent dose $=0.5 \mathrm{~g} / \mathrm{L}$; contact time $=12 \mathrm{~h} ; \mathrm{T}=40^{\circ} \mathrm{C} ; \mathrm{pH}=6.0$ for $\mathrm{Cr}$ (III) and 8.0 for Ni (II))
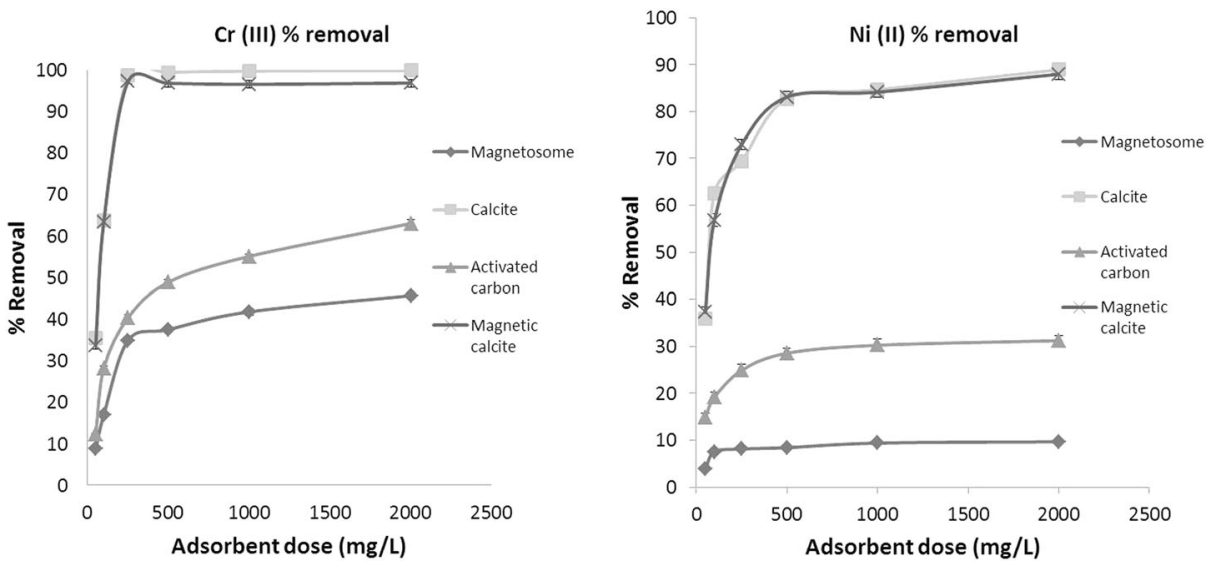

Fig. 7 Effect of adsorbent dose on equilibrium $\mathrm{Cr}$ (III) and Ni (II) adsorption capacity of magnetosome, activated carbon, magnetic calcite and activated calcite $\left(C_{0}=10 \mathrm{~g} / \mathrm{L}\right.$; contact time $=12 \mathrm{~h} ; \mathrm{T}=40^{\circ} \mathrm{C} ; \mathrm{pH}=6.0$ for $\mathrm{Cr}$ (III) and 8.0 for Ni (II))

equilibrium point (Fig. 8). The equilibrium for $\mathrm{Cr}$ (III) and $\mathrm{Ni}$ (II) was established after $30 \mathrm{~min}$ for all the four adsorbents. The adsorption capacity was found to be constant after the equilibrium point. High adsorption capacity in the initial stages is as a result of the availability of more active sites on the surface of the adsorbent which gets saturated further. ${ }^{26}$

\section{Adsorption kinetics}

The adsorption process could be dependent on different mechanisms, such as particle diffusion, mass transfer or chemical reactions. The pseudo-first-order kinetic model, pseudo-secondorder kinetic model, and intra-particle diffusion model were used to determine the kinetic mechanism of the adsorption process. 
$\mathrm{Cr}$ (III) adsorption capacity with time

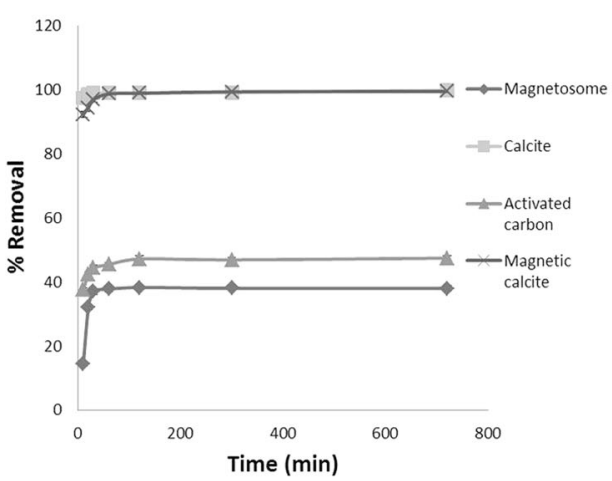

$\mathrm{Ni}$ (II) adsorption capacity with time

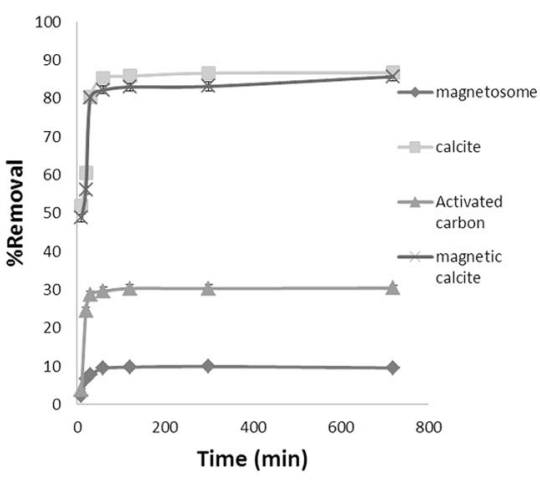

Fig. 8 Effect of contact time on equilibrium $\mathrm{Cr}$ (III) and Ni (II) adsorption capacity of magnetosome, activated carbon, magnetic calcite and activated calcite (biosorbent dose $=0.5 \mathrm{~g} / \mathrm{L} ; \mathrm{C}_{0}=10 \mathrm{~g} / \mathrm{L} ; T=40^{\circ} \mathrm{C} ; \mathrm{pH}=6.0$ for $\mathrm{Cr}$ (III) and 8.0 for Ni (II))

The pseudo-first-order kinetic model of Lagergren describes the rate of occupied adsorbed sites is proportional to the rate of unoccupied sites. The linear form of the pseudo-first-order equation (1) is given as follows: ${ }^{27}$

$\log \left(q_{\mathrm{e}}-q_{\mathrm{t}}\right)=\log q_{\mathrm{e}}-k_{1} t / 2.303$

where $q_{\mathrm{t}}$ and $q_{\mathrm{e}}$ are adsorption capacities at equilibrium $(\mathrm{mg} / \mathrm{g})$ and time $t$ and $k_{1}$ is the pseudo-first-order rate constant $\left(\min ^{-1}\right)$. A linear plot of $\log \left(q_{\mathrm{e}}-q_{\mathrm{t}}\right)$ vs. $t$ provided the values of $k_{1}$ and $q_{\mathrm{e}}$ from the slope and intercept, respectively. The validity of the adsorption mechanism is based on the values of the regression coefficient, $R^{2}$, and the predicted $q_{\mathrm{e}}$ values obtained. The $R^{2}$ value for all four adsorbents does not fit to the adsorption process, and the predicted $q_{\mathrm{e}}$ were different from calculated $q_{\mathrm{e}}$. Hence the adsorption process does not show good agreement with the pseudo-first-order kinetic model.

The pseudo-second-order kinetic model implies chemisorption during the adsorption process. ${ }^{28}$ It is expressed as

$\frac{t}{q_{\mathrm{t}}}=\frac{1}{k_{2} q_{\mathrm{e}}^{2}}+\frac{1}{q_{\mathrm{e}}} t$

where $q_{\mathrm{t}}$ and $q_{\mathrm{e}}$ are adsorption capacities at equilibrium $(\mathrm{mg} / \mathrm{g})$ and time $t$ and $k_{2}$ is the pseudo-second-order rate constant $(\mathrm{g} / \mathrm{mL}$ min). The linear plot of $t / q_{\mathrm{t}}$ vs. $t$ provided the values of $k_{2}$ and $q_{\mathrm{e}}$ from the slope and intercept as recorded in Table 1 . The experimental and calculated $q_{\mathrm{e}}$ values are comparable, and the values of $R^{2}$ for the pseudo-second-order kinetic model are high (all greater than 0.9). Hence adsorption of $\mathrm{Cr}$ (III) and $\mathrm{Ni}$ (II) by all four adsorbents showed good fit into pseudo-second order equation, and chemisorption is one possible mechanism of adsorption for both $\mathrm{Cr}$ (III) and $\mathrm{Ni}$ (II).

To elucidate the mechanism of adsorption process, the intraparticle diffusion model was applied, and the model equation is expressed as follows: ${ }^{29}$

$q_{\mathrm{t}}=K_{\mathrm{d}} t^{1 / 2}+C$

where $q_{\mathrm{t}}$ is adsorption capacities at time $t$ and $K_{\mathrm{d}}$ represents the intraparticle diffusion rate constant, and $C$ is the intercept. $A$ linear plot of $q_{\mathrm{t}}$ vs. $t^{1 / 2}$ is linear and passes through the origin. The $R^{2}$ values for intra-particle diffusion model are high in both the intervals (linear and equilibrium). Therefore adsorption of $\mathrm{Cr}$ (III) and $\mathrm{Ni}$ (II) by all the four adsorbents follows a possible mechanism of intra-particle diffusion. However, the $C$ value is greater than 0 , hence intra-particle diffusion is not the rate determining step in the adsorption process.

\section{Adsorption isotherms}

Adsorption isotherm explains the equilibrium between metal ions adsorbed by the adsorbent to the metal ion present in the solution. The adsorbent capacity of the adsorbent was calculated to design the adsorption system to remove maximum pollutant (metal ions). The Langmuir, Freundlich isotherm models have been used to investigate the effect of initial metal concentrations on adsorbent capacity at different temperatures.

The Langmuir isotherm is used to describe a monolayer adsorption onto the surface of an adsorbent, and the linear form is expressed as follows: ${ }^{30}$

$\frac{C_{e}}{q_{e}}=\frac{1}{q_{o} K_{L}}+\frac{1}{q_{0}} C_{e}$

where $C_{\mathrm{e}}(\mathrm{mg} / \mathrm{L})$ is the equilibrium concentration, $q_{\mathrm{e}}(\mathrm{mg} / \mathrm{g})$ is the adsorption capacity at equilibrium, $q_{0}$ are the Langmuir constants related to the adsorption capacity and $K_{\mathrm{L}}$ is the rate of adsorption. To find the Langmuir constants $C_{\mathrm{e}} / q_{\mathrm{e}}$ was plotted against $C_{\mathrm{e}}$, a straight line with a slope of $1 / q_{0}$ was obtained. The isotherm parameters are computed in Table 2. The correlation coefficient $\left(R^{2}\right)$ is high (all greater than 0.9). Hence good agreement of the Langmuir isotherm was observed based on the experimental data for all the four adsorbents.

The Freundlich isotherm determines the ability of adsorbents in non-ideal sorption on heterogeneous surfaces. The linear form is expressed $\mathrm{as}^{31}$

$\ln q_{\mathrm{e}}=\ln K_{\mathrm{F}}+\frac{1}{n} \ln C_{\mathrm{e}}$

where $q_{\mathrm{e}}$ is the amount of adsorption capacity at equilibrium (mg/ g) and $C_{\mathrm{e}}$ is the equilibrium concentration of metal ions. $K_{\mathrm{F}}$ and $n$ are Freundlich constants, where $K_{\mathrm{F}}$ and $1 / n$ are the adsorption capacity of the adsorbent. The plot of $\ln q_{\mathrm{e}} \mathrm{vs}$. $\ln C_{\mathrm{e}}$ gives linear plot with slope $1 / n$. Freundlich constants ( $K_{\mathrm{F}}$ and $\left.n\right)$ were calculated and are shown in Table 2 . High $R^{2}$ values show good agreement with the Freundlich model and the value of $n$ gives an indication of how favourable the adsorption process is. Since all the values of $n$ are between 1 and 10, favourable adsorption has been carried out by the selected adsorbents.

\section{Adsorption thermodynamics}

The Gibbs free energy changes were calculated by using the equilibrium constants obtained from Langmuir isotherm. The integrated form of this equation is expressed as

$\ln K_{\mathrm{L}}=\frac{\Delta S^{\circ}}{R}-\frac{\Delta H^{\circ}}{R} \frac{1}{T}$

Gibbs free energy $\Delta G^{\circ}$ for each temperature is obtained from the equation

$\Delta G^{\circ}=\Delta H^{\circ}-T \Delta S^{\circ}$ 
Table 1. (a) Coefficients of pseudo-first-order and pseudo-second-order adsorption kinetic models and intraparticle diffusion model (Cr (III) metal ion $=500 \mathrm{mg} / \mathrm{L}$ ). (b) Coefficients of pseudo-first-order and pseudo-second-order adsorption kinetic models and intraparticle diffusion model (Ni (II) metal ion $=500 \mathrm{mg} / \mathrm{L})$

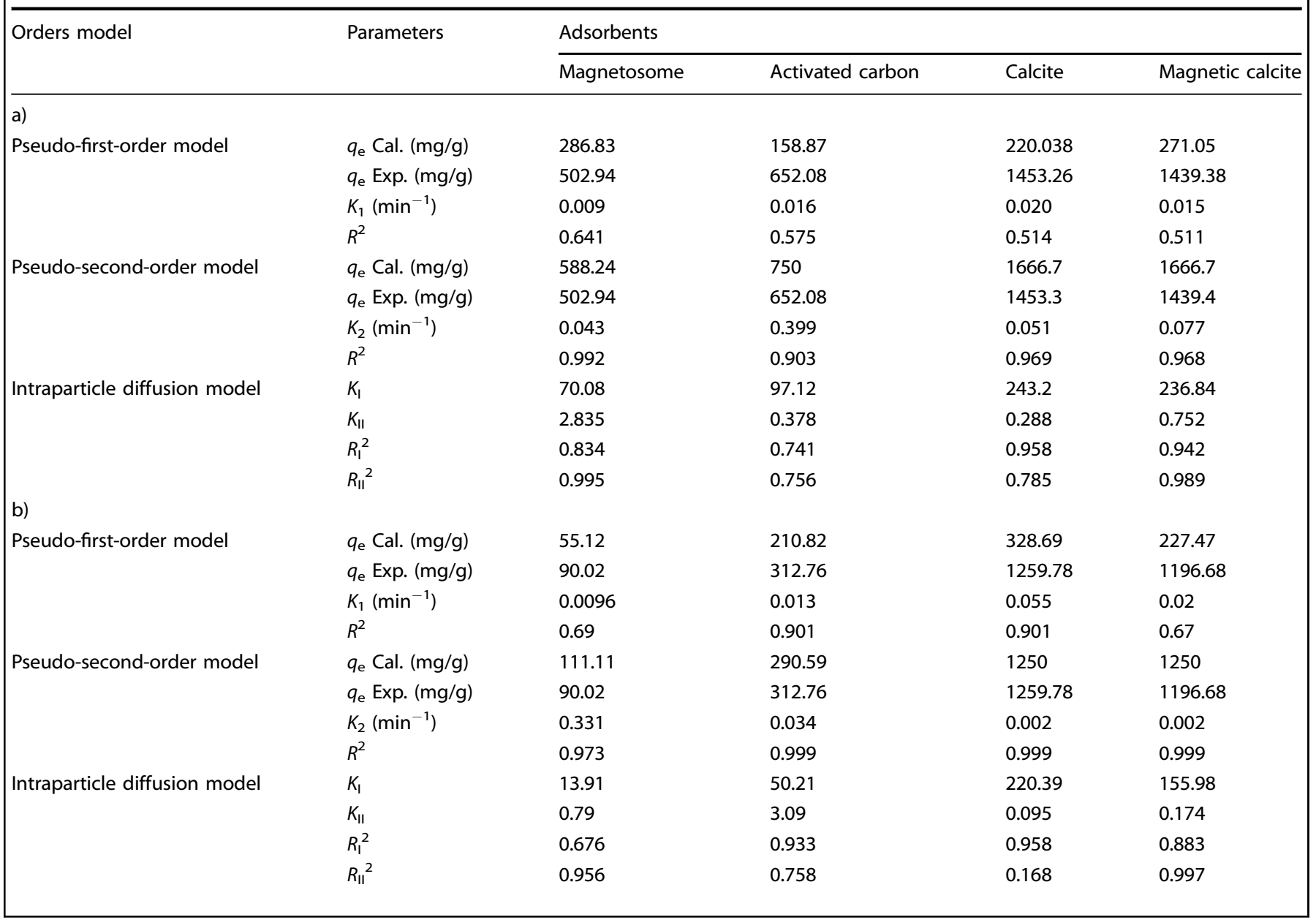

Table 2. (a) Isotherm parameters for removal of $\mathrm{Cr}$ (III) metal ions, (b) isotherm parameters for removal of Ni (II) metal ions

\begin{tabular}{|c|c|c|c|c|c|}
\hline \multirow[t]{3}{*}{ Langmuir } & $q_{0}(\mathrm{mg} / \mathrm{g})$ & 4.762 & 5.88 & 20 & 20 \\
\hline & $K_{\mathrm{L}}(\mathrm{L} / \mathrm{mg})$ & 0.274 & 0.274 & 0.132 & 0.136 \\
\hline & $R^{2}$ & 0.961 & 0.951 & 0.964 & 0.947 \\
\hline Freundlich & $R^{2}$ & 0.867 & 0.862 & 0.929 & 0.923 \\
\hline \multicolumn{6}{|l|}{ b) } \\
\hline \multirow[t]{3}{*}{ Langmuir } & $q_{0}(\mathrm{mg} / \mathrm{g})$ & 2.083 & 3.704 & 100 & 100 \\
\hline & $K_{\mathrm{L}}(\mathrm{L} / \mathrm{mg})$ & 0.072 & 0.189 & 0.0143 & 0.016 \\
\hline & $R^{2}$ & 0.982 & 0.976 & 0.878 & 0.938 \\
\hline
\end{tabular}


The calculated Gibbs free energy changes, standard enthalpy and entropy changes were determined from the $\ln K_{\mathrm{b}}$ vs. $1 / T$ plot and values are shown in Table 3. The positive $\Delta H^{\circ}$ endothermic nature of biosorption and the positive value of $\Delta S^{\circ}$ confirm the increased randomness at the solid-solution interface during biosorption.

Adsorption of $\mathrm{Cr}$ (III) and $\mathrm{Ni}$ (II) from tannery effluent

Sample analysis. The chromium and nickel content were estimated by atomic absorption (http://www.epa.gov). The concentration of $\mathrm{Cr}$ (III) was found to be $12.8 \mu \mathrm{g} / \mathrm{mL}$, and concentration of nickel in water sample was found to be $1.69 \mu \mathrm{g} / \mathrm{mL}$. The maximum permissible concentration in water as defined by USEPA (2003) was 0.05 and $0.02 \mu \mathrm{g} / \mathrm{mL}$ for $\mathrm{Cr}$ (III) and Ni (II), respectively.

Adsorption. Adsorption of $\mathrm{Cr}$ (III) and Ni (II) from tannery effluent was carried out in previously standardised optimum conditions. The synthesised magnetic crystal removed $94 \%$ of $\mathrm{Cr}$ (III) and $84 \%$ of $\mathrm{Ni}$ (II) from the effluent (Table 4). The \% removal is identical to calcite crystals and higher than bacterial magnetosomes and

Table 3. Adsorption thermodynamic parameters: (a) $\mathrm{Cr}$ (III) and (b) $\mathrm{Ni}$ (II)

\begin{tabular}{llll}
\hline Adsorbent & $\Delta G^{\circ}$ & $\Delta S^{\circ}$ & $\Delta H^{\circ}$ \\
\hline a) & & & \\
Magnetosome & Negative & 0.096 & 36.51 \\
Activated carbon & Negative & 0.049 & 19.11 \\
Calcite & Negative & 0.0659 & 30.97 \\
Magnetic calcite & Negative & 0.1075 & 42.92 \\
b) & & & \\
Magnetosome & Negative & 0.0108 & 6.7194 \\
Activated carbon & Negative & 0.0105 & 6.39 \\
Calcite & Negative & 0.103 & 35.26 \\
Magnetic calcite & Negative & 0.0195 & 9.96 \\
\hline
\end{tabular}

activated carbon. EDS and FTIR analyses of tannery effluent treated adsorbent confirmed the absorbance of $\mathrm{Cr}$ (III) and Ni (II). EDS analysis of treated magnetic calcite showed $2.79 \%$ of $\mathrm{Cr}$ (III) and $1.6 \% \mathrm{Ni}$ (II) in weight percentage. Calcite microcrystals showed 2.84 and $1.47 \%$ of $\mathrm{Cr}$ (III) and $\mathrm{Ni}$ (II), respectively (Fig. 9). FTIR analysis of treated calcite and magnetic calcite showed the presence of $\mathrm{Cr}$ (III) and $\mathrm{Ni}$ (II) in absorption peaks from 400 to $500 \mathrm{~cm}^{-1}$ (Fig. 10). The removal efficiency of $\mathrm{Cr}$ (III) and Ni (II) by magnetic calcite was compared with other adsorbents (Table 5).

The usage of magnetic calcite crystal as an alternate method for the removal of heavy metals ( $\mathrm{Cr}$ (III) and Ni (II)) from tannery effluent water is promising. The produced magnetic calcite crystal was characterised and batch adsorption experiments for the removal of $\mathrm{Cr}$ (III) and Ni (II) have been carried out. The magnetic property of magnetosomes can be used for the separation of heavy metal ions after treatment. The adsorption experiment results followed second-order kinetic model and the values fit in with the Langmuir and Freundlich isotherms. Future work should consider the dynamic flow column experiments to assess the feasibility and to design a removal system for field operation. Parameters such as the effectiveness, capacity, and longevity of reactive materials should be assessed. Certain factors such as precipitate formation and loss of porosity cannot be accurately determined by batch experiments. The current results suggest that exploration of new, efficient, inexpensive materials as heavy metal removal system improve the existing system.

\section{METHODS}

Cultivation of MTB

Magnetospirillum sp. VITRJS2 strain was isolated from sediment in Thenpennai Lake, Cuddalore, located in India. The strain RJS2 was phylogenetically affiliated with the Alphaproteobacteria and biomineralize cubo-octahedral magnetosomes. ${ }^{32}$ For cultivation, the strain was subcultured in Magnetospirillum growth medium (MSGM) as described by Blakemore et al. ${ }^{33}$ Hungate anaerobic technique was followed for the culturing of the bacteria. ${ }^{34}$ About $50 \mathrm{~mL}$ of the media was transferred to $100 \mathrm{~mL}$ serum bottles and sparged with sterile nitrogen gas to create redox condition. The culture bottles were closed with butyl rubber stoppers and sealed with aluminium caps and sterilised by autoclaving. Before

\begin{tabular}{|lllllll|}
\hline Table 4. & Percentage adsorption of $\mathrm{Cr}$ (III) and Ni (II) from tannery effluent & & & \\
\hline Metal ions & Initial concentration, $C_{\mathrm{i}}(\mathrm{mg} / \mathrm{L})$ & Final concentration, $\mathrm{C}_{\mathrm{o}}$ (mg/L) & Volume (L) & Adsorbent dose (g) & $\begin{array}{l}\text { Adsorption } \\
\text { capacity (mg/g) }\end{array}$ \\
\hline $\mathrm{Cr}$ (III) & 12.8 & 0.7 & 0.1 & 0.05 & 24.2 & 94 \\
$\mathrm{Ni}$ (II) & 1.69 & 0.27 & 0.1 & 0.05 & 2.84 \\
\hline
\end{tabular}
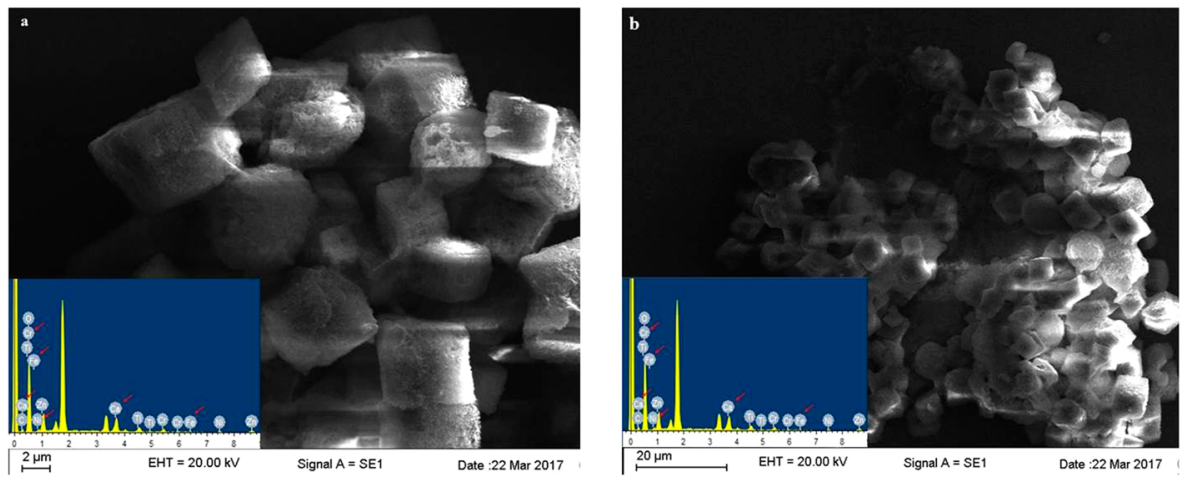

Fig. 9 SEM/EDS analysis of tannery effluent treated (a) calcite microcrystals showed $2.84 \%$ and $1.47 \%$ of $\mathrm{Cr}$ (III) and Ni (II) in weight percentage, respectively. (b) Magnetic calcite shows $2.79 \%$ of $\mathrm{Cr}$ (III) and $1.6 \% \mathrm{Ni}$ (II) in weight percentage 


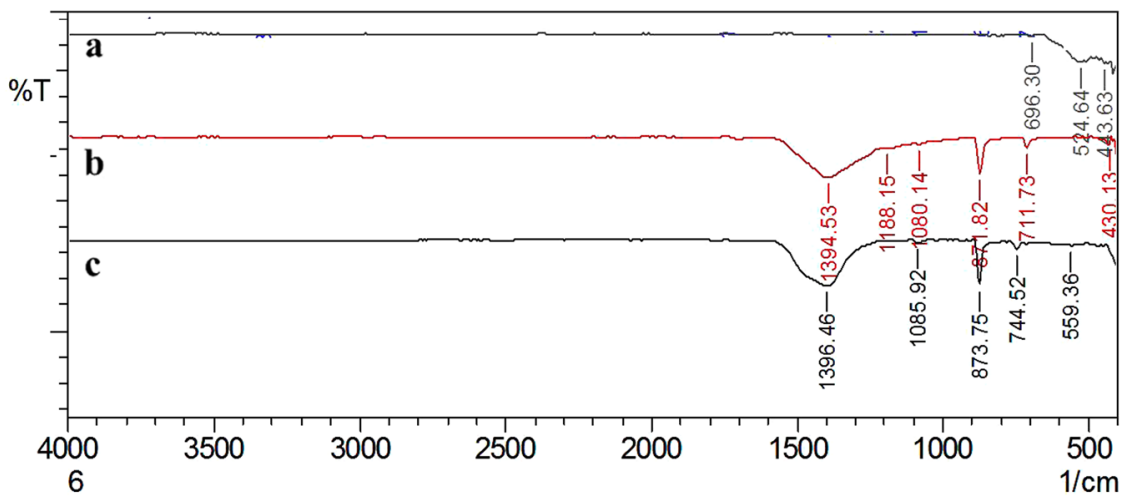

Fig. 10 FTIR analysis of tannery effluent treated (a) magnetosomes shows characteristic Fe-O peaks at 443 and $524 \mathrm{~cm}^{-1}$, (b) calcite shows peaks of calcium at the absorption, 711 and $871 \mathrm{~cm}^{-1}$ and bands of carbonate were found at $1080 \mathrm{~cm}^{-1}$ and (c) magnetic calcite possesses both magnetite $\left(443 / 524 \mathrm{~cm}^{-1}\right)$ and calcite $\left(711 / 871 \mathrm{~cm}^{-1}\right)$ peaks. The new peak that appear after the treatment at $1396 \mathrm{~cm}-1$ corresponds to the adsorbed $\mathrm{Cr}$ (III) and $\mathrm{Ni}$ (II). The appearance of new peak may be due to the interaction between the functional groups and metal ions

\begin{tabular}{|c|c|c|c|}
\hline \multirow[t]{2}{*}{ Materials } & \multicolumn{2}{|c|}{$\begin{array}{l}\text { Adsorption } \\
\text { capacity (mg/ } \\
\text { g) }\end{array}$} & \multirow[t]{2}{*}{ References } \\
\hline & $\mathrm{Cr}$ (III) & $\overline{\mathrm{Ni}(\mathrm{II})}$ & \\
\hline Rice husk & 0.79 & - & 39,40 \\
\hline sRaw rice bran & 0.8 & 0.78 & 41 \\
\hline Sawdust & - & 0.229 & 42,43 \\
\hline Orange peel & - & 158 & 44 \\
\hline Cococut shell charcoal & 3.65 & - & 45 \\
\hline Modified rice hull & 23.4 & - & 46 \\
\hline Red mud & - & 160 & 47 \\
\hline Soya cake & - & 0.7 & 48 \\
\hline Activated alumina & 1.6 & - & 49 \\
\hline Activated charcoal & 0.9614 & - & \\
\hline Wheat bran & 0.942 & - & 50 \\
\hline Activated rice husk carbon & 0.8 & - & 39 \\
\hline Pine leaves & 0.277 & - & 43 \\
\hline Modified oak sawdust & 1.7 & 3.29 & 51 \\
\hline CETYL-amended zeolite & 0.65 & - & 52 \\
\hline Cornelian cherry & 59.4 & - & 53 \\
\hline Apricot stone & 58.86 & - & \\
\hline Almond shells & 59.64 & - & \\
\hline $\begin{array}{l}\text { Sodium carboxy methyl cellulose stabilised } \\
\text { iron nanoparticles }\end{array}$ & 255 & - & 54 \\
\hline Scrap Iron & 19 & - & 55 \\
\hline $\mathrm{Fe} @ \mathrm{SiO}_{2}$ & 467 & - & 56 \\
\hline lon exchange resin & - & 138 & 57 \\
\hline Wool & 41.2 & - & 58 \\
\hline Olive cake & 33.4 & - & \\
\hline Chemical precipitation $(\mathrm{NaOH})$ & - & 9.6 & 59 \\
\hline Magnetic calcite & 24.2 & 2.84 & This study \\
\hline
\end{tabular}

inoculation, sterile vitamin and ferric quinate solution was added using hypodermic syringe through the rubber closure without disturbing the anoxic environment inside the culture bottle. The media was then inoculated with Magnetospirillum sp. culture and incubated in the shaker incubator for 3 days at room temperature $\left(28^{\circ} \mathrm{C}\right)$.
Magnetosome extraction and characterisation

Extraction of the magnetosomes from MTB was carried out according to the modified method described by Alphandery et al. ${ }^{35}$ The bacterial cells in logarithmic phase were separated from the culture medium by centrifugation $(4000 \times g$ for $20 \mathrm{~min})$. The pellet was re-suspended in PBS $(0.01 \mathrm{M}, \mathrm{pH} 7.4)$ and washed repeatedly by centrifugation. Further the cell pellet was re-suspended in Tris- $\mathrm{HCl}$ buffer $(0.1 \mathrm{M}, \mathrm{pH} 7.0)$ and the cell membranes were disrupted by ultrasonication (Sonics Vibracell, USA) at $30 \mathrm{~W}$ for $2 \mathrm{~h}$. The magnetosomes extract was repeatedly purified by magnetic separation and the extracted magnetosomes were freeze dried (Lark, Penguin Classic Plus, India) and stored for further use.

Preparation of calcite and calcite-coated bacterial magnetosomes The stable form of calcium carbonate microcrystals $\left(\mathrm{CaCO}_{3}\right)$ was prepared by mixing an equal volume of $100 \mathrm{mM} \mathrm{CaCl}$ solution and $\mathrm{Na}_{2} \mathrm{CO}_{3}$ solution under vigorous mixing. The precipitated solid was collected and immediately filtered through cellulose nitrate membrane $(0.2 \mu \mathrm{m})$ and dried under vacuum. ${ }^{36}$

The $\mathrm{CaCO}_{3}$ coated magnetosomes were fabricated by mixing equal volume of $0.33 \mathrm{M} \mathrm{CaCl}_{2}$ solution and $\mathrm{Na}_{2} \mathrm{CO}_{3}$ in the presence of vigorously stirred magnetosome $(50 \mathrm{mg} / \mathrm{mL})$. The precipitate was filtered through cellulose nitrate membrane $(0.2 \mu \mathrm{m})$ and dried at $70^{\circ} \mathrm{C}$ for $30 \mathrm{~min}^{37}$ The magnetic calcite crystals were further purified by magnetic separation, and excess $\mathrm{CaCO}_{3}$ was removed by several washing.

\section{Characterisation of adsorbent}

Magnetosomes, calcite and calcium carbonate coated magnetosomes were characterised by scanning electron microscopy (SEM/EDS; ZEISS EV018, Germany) and Fourier transforms infrared (FTIR; Shimadzu, Japan) spectral measurements.

\section{Adsorption experiments}

All adsorption parameters were measured in batch system. Different metal ion concentrations were prepared in deionized water. The effect of various factors, such as contact time (10-720 min), $\mathrm{pH}(2-8)$, temperature $\left(20-40^{\circ}\right.$ C), adsorbent dosage $(0-2000 \mathrm{mg} / \mathrm{L})$ and initial metal concentration $(0-2000 \mathrm{mg} / \mathrm{L})$ on adsorption capacity were examined. Batch experiments were carried out in $250 \mathrm{~mL}$ Erlenmeyer flasks containing $50 \mathrm{~mL}$ metal solution and agitated on an orbital shaker at $150 \mathrm{rpm}$. Unless otherwise conditions specified adsorption experiments were conducted at $\mathrm{pH}(7)$, temperature $\left(30^{\circ} \mathrm{C}\right)$, adsorbent dosage $(500 \mathrm{mg} / \mathrm{L})$ and initial metal concentration $(500 \mathrm{mg} / \mathrm{L})$. Samples were withdrawn at predetermined time intervals and centrifuged at $5000 \mathrm{rpm}$ for $10 \mathrm{~min}$. The residual metal concentration of the supernatant was determined by atomic absorption analysis (AAS Varian AA240). All the experiments were carried out in triplicates, and average values were used in the data analysis.

The amount of heavy metal adsorbed was calculated using the following equation:

$q=\frac{\left(C_{0}-C_{\mathrm{e}}\right) V}{M}$ 
where $q$ is the amount of metal adsorbed per gram of adsorbent, $C_{0}$ is the initial concentration of metal ion $(\mathrm{mg} / \mathrm{L}), C_{e}$ is the final concentration of metal ion (mg/L), $V$ is the initial volume of the adsorption medium (L), and $M$ is the mass of the adsorbent (g).

The removal efficiency (\%) and equilibrium adsorbed concentration, $q$ $(\mathrm{mg} / \mathrm{g})$ of metal ions were calculated as follows:

Removal efficiency $(\%)=\frac{C_{0}-C_{t}}{C_{0}} \times 100$

Kinetic parameters

To explain the mechanism of adsorption kinetic equation for pseudo-firstorder, pseudo-second order and intra-particle diffusion model have been used to test experimental data.

\section{Equilibrium parameters}

Langmuir and Freundlich adsorption isotherm studies were conducted to explain the equilibrium between metal ions adsorbed and metal ions in solution.

\section{Thermodynamic parameters}

Gibbs free energy change of adsorption $\left(\Delta G^{0}\right)$, enthalpy $\left(\Delta H^{0}\right)$ and entropy $\left(\Delta S^{0}\right)$ changes of the adsorption process have been calculated.

\section{Adsorption of $\mathrm{Cr}$ (III) and $\mathrm{Ni}$ (II) from tannery effluent}

Study area and sample collection. The effluent sample was collected from highly contaminated tannery effluent discharge site in Palar River basin with the geographical location of $12.78^{\circ} \mathrm{N}$ latitude $78.7^{\circ} \mathrm{E}$ longitude. The discharged effluent was found to have polluted the Puliathengal, Vanapadi, Pinji and Thandalam lakes in the Palar River basin. ${ }^{38}$ The physical appearance, $\mathrm{pH}$ and temperature of the samples were recorded onsite after sample collection. The presence of $\mathrm{Cr}$ (III) and $\mathrm{Ni}$ (II) in the samples were estimated by atomic absorption spectrophotometer (Varian Spectra AA240). Total chromium and nickel were measured with the respective working standard. The results are presented as means and standard deviation of each mean $(n=3)$.

\section{Adsorption capacity of $\mathrm{Cr}$ (III) and Ni (II)}

Adsorption experiments were performed in triplicates in optimal operational parameters such as $\mathrm{pH}$, contact time, temperature and adsorbent dosage. Adsorption experiment for the removal of $\mathrm{Cr}$ (III) was conducted at $\mathrm{pH}(6.0)$, temperature $\left(40^{\circ} \mathrm{C}\right)$, contact time $(60 \mathrm{~min})$ and adsorbent dosage $(500 \mathrm{mg} / \mathrm{L})$. The recovery of $\mathrm{Ni}$ (II) from the tannery effluent was conducted in similar parameters except for the $\mathrm{pH}$ (8.0). After the adsorption experiment, the solution was filtered, and residual concentration of metal ions was measured using AAS (Varian Spectra AA240). Removal efficiency (\%) and adsorption capacity were calculated. The adsorption capacity of calcite and magnetic calcite was analysed using EDS and FTIR analyses.

Data availability statement

Sequences of the 16S rRNA gene determined in this study were assigned the GenBank accession numbers. The newly determined sequences of Magnetospirillum strains VITRJS2, has been deposited under the accession numbers KJ570852.

\section{ACKNOWLEDGEMENTS}

This work was supported by Science and Engineering Research Board, Department of Science \& Technology, Government of India (Grant \#SR/FT/LS-11/2012). The authors also wish to thank Technology Business Incubator (TBI-VIT), sponsored by the Department of Science and Technology, for atomic absorption spectrometry analysis and School of Advanced Sciences, Chemistry Division, VIT University for FTIR analysis. We would like to thank Sophisticated Test and Instrumentation Centre (STIC), CUSAT, Cochin, India for assistance with acquisition of TEM images.

\section{AUTHOR CONTRIBUTIONS}

K.S. gave the concept about the work. J.J.J. designed the work and analysed the data R.V. and S.G. helped in data collection. J.J.J. interpreted the data and drafted the article. M.A.J. and K.S. have done the critical revision of the article. K.S. has done the final correction of the manuscript and approved the version to be published.

\section{ADDITIONAL INFORMATION}

Competing interests: The authors declare no competing interests.

Publisher's note: Springer Nature remains neutral with regard to jurisdictional claims in published maps and institutional affiliations.

\section{REFERENCES}

1. Peralta-Videa, J. R., Lopez, M. L., Narayan, M., Saupe, G. \& Gardea-Torresdey, J. The biochemistry of environmental heavy metal uptake by plants: implications for the food chain. Int. J. Biochem. Cell Biol. 41, 1665-1677 (2009).

2. Alloway, B.J. Soil processes and the behaviour of metals. Heavy metals in soils. 38-57 (1995)

3. Lokhande, R. S., Singare, P. U. \& Pimple, D. S. Study on physico-chemical parameters of waste water effluents from Taloja industrial area of Mumbai, India. Int J. Ecosyst. 1, 1-9 (2011).

4. Tchounwou, P. B., Yedjou, C. G., Patlolla, A. K. \& Sutton, D. J. Heavy metal toxicity and the environment. EXS. 101, 133-164 (2012).

5. Förstner, U. \& Wittmann, G.T. Metal Pollution in the Aquatic Environment. Springer Science \& Business Media (Springer-Verlag, Berlin, Germany, 2012).

6. Nasrullah, N. R., Bibi, H., Iqbal, M. \& Durrani, M. I. Pollution load in industrial effluent and ground water of Gadoon Amazai Industrial Estate (GAIE) Swabi, NWFP. J. Agric. Biol. Sci. 1, 18-24 (2006).

7. Aravindhan, R., Madhan, B., Rao, J. R., Nair, B. U. \& Ramasami, T. Bioaccumulation of chromium from tannery wastewater: an approach for chrome recovery and reuse. Environ. Sci. Technol. 38, 300-306 (2004).

8. Roy, S., Nagarchi, L., Das, I., Mangalam, A. J. \& Krishnamurthy, S. Cytotoxicity, genotoxicity, and phytotoxicity of tannery effluent discharged into Palar River Basin, Tamil Nadu, India. J. Toxicol. 2015, 1-9 (2015).

9. Barakat, M. A. New trends in removing heavy metals from industrial wastewater Arab. J. Chem. 4, 361-377 (2011).

10. Bailey, S. E., Olin, T. J., Bricka, R. M. \& Adrian, D. D. A review of potentially low-cost sorbents for heavy metals. Water Res. 33, 2469-2479 (1999).

11. Aziz, H. A. \& Smith, P. G. The influence of $\mathrm{pH}$ and coarse media on manganese precipitation from water. Water Res. 26, 853-855 (1992).

12. Aziz, H. A., Adlan, M. N. \& Ariffin, K. S. Heavy metals (Cd, Pb, Zn, Ni, Cu and Cr (III)) removal from water in Malaysia: post treatment by high quality limestone. Bioresour. Technol. 99, 1578-1583 (2008).

13. Dvorak, D. H., Hedin, R. S., Edenborn, H. M. \& McIntire, P. E. Treatment of metalcontaminated water using bacterial sulfate reduction: Results from pilot-scale reactors. Biotechnol. Bioeng. 40, 609-616 (1992).

14. Song, H., Xingang, L.I., Sun, J. \& Wang, Y. Heavy metals removal from wastewater by magnetic field-magnetotactic bacteria technology. In Annual Meeting on Water Resource Conservation: Purification, Reclamation and Reuse, Vol. 16 (American Institute of Chemical Engineers, New York, 2006).

15. Gupta, V. K. et al. Nanoparticles as adsorbent; a positive approach for removal of noxious metal ions: a review. Sci. Technol. Dev. 34, 195-214 (2015).

16. $\mathrm{Xu}, \mathrm{P}$. et al. Use of iron oxide nanomaterials in wastewater treatment: a review. Sci. Total Environ. 424, 1-10 (2012).

17. Komeili, A. Molecular mechanisms of compartmentalization and biomineralization in magnetotactic bacteria. FEMS Microbiol. Rev. 36, 232-255 (2012).

18. Liu, Y., Li, G. R., Guo, F. F., Jiang, W., Li, Y. \& Li, L. J. Large-scale production of magnetosomes by chemostat culture of Magnetospirillum gryphiswaldense at high cell density. Microb. Cell Fact. 9, 1 (2010).

19. Bini, R. A., Marques, R. F. C., Santos, F. J., Chaker, J. A. \& Jafelicci, M. Synthesis and functionalization of magnetite nanoparticles with different amino-functional alkoxysilanes. J. Magn. Magn. Mater. 324, 534-539 (2012).

20. Willis, A. L., Turro, N. J. \& O'Brien, S. Spectroscopic characterization of the surface of iron oxide nanocrystals. Chem. Mater. 17, 5970-5975 (2005).

21. Saraya, M. E. S. I. \& Rokbaa, H. H. A. L. Preparation of vaterite calcium carbonate in the form of spherical nano-size particles with the aid of polycarboxylate superplasticizer as a capping agent. Am. J. Nanomater. 4.2, 44-51 (2016).

22. Kara, A. \& Demirbel, E. Kinetic, isotherm and thermodynamic analysis on adsorption of $\mathrm{Cr}(\mathrm{VI})$ ions from aqueous solutions by synthesis and characterization of magnetic-poly (divinylbenzene-vinylimidazole) microbeads. Water Air Soil Pollut. 223, 2387-2403 (2012).

23. Al-Homaidan, A. A., Al-Houri, H. J., Al-Hazzani, A. A., Elgaaly, G. \& Moubayed, N. M Biosorption of copper ions from aqueous solutions by Spirulina platensis biomass. Arab. J. Chem. 7, 57-62 (2014). 
24. Arshadi, M., Amiri, M. J. \& Mousavi, S. Kinetic, equilibrium and thermodynamic investigations of $\mathrm{Ni}$ (II), Cd (II), Cu (II) and Co (II) adsorption on barley straw ash. Water Resour. Ind. 6, 1-17 (2014).

25. Desta, M. B. Batch sorption experiments: Langmuir and Freundlich isotherm studies for the adsorption of textile metal ions onto teff straw (Eragrostis tef) agricultural waste. J. Thermodyn. 2013, 1-6 (2013).

26. Dursun, A. Y. A comparative study on determination of the equilibrium, kinetic and thermodynamic parameters of biosorption of copper (II) and lead (II) ions onto pretreated Aspergillus niger. Biochem. Eng. J. 28, 187-195 (2006).

27. Lagergren, S. About the theory of so-called adsorption of soluble substances. Kungliga Svenska Vetenskapsakademiens. Handlingar 24, 1-39 (1898).

28. Ho, Y. S. \& McKay, G. Pseudo-second order model for sorption processes. Process Biochem. 34, 451-465 (1999).

29. Osman, B., Kara, A. \& Beşirli, N. Immobilization of glucoamylase onto Lewis metal ion chelated magnetic affinity sorbent: kinetic, isotherm and thermodynamic studies. J. Macromol. Sci. 48, 387-399 (2011).

30. Tekin, N., Kadıncı, E., Demirbaş, Ö., Alkan, M. \& Kara, A. Adsorption of polyvinylimidazole onto kaolinite. J. Colloid Interface Sci. 296, 472-479 (2006).

31. Kara, A., Acemioğlu, B., Alma, M. H. \& Cebe, M. Adsorption of $\mathrm{Cr}$ (III), Ni (II), Zn (II), Co (II) ions onto phenolated wood resin. J. Appl. Polym. Sci. 101, 2838-2846 (2006).

32. Jacob, J. J., Revathy, T., Jayasri, M. A. \& Suthindhiran, K. Diversity of Magnetospirillum sp. from the southern coast of India. Curr. Sci. 110, 178-183 (2016).

33. Blakemore, R. P., Maratea, D. \& Wolfe, R. S. Isolation and pure culture of a fresh water magnetic spirillium inchemically defined medium. J. Bacteriol. 140, 720-729 (1979).

34. Hungate, R. E. A roll tube method for cultivation of strict anaerobes. Method Microbiol. 3, 117-132 (1969).

35. Alphandery, E., Faure, S., Seksek, O., Guyot, F. \& Chebbi, I. Chains of magnetosomes extracted from AMB-1 magnetotactic bacteria for application in alternative magnetic field cancer therapy. ACS Nano 5, 6279-6296 (2011).

36. Nan, Z. D., Shi, Z. Y., Qin, M., Hou, W. G. \& Tan, Z. C. Formation process and thermodynamic poperties of calcite. Chin. J. Chem. 25, 592-595 (2007).

37. Fakhrullin, R. F., Bikmullin, A. G. \& Nurgaliev, D. K. Magnetically responsive calcium carbonate microcrystals. ACS Appl. Mater. Interfaces 1, 1847-1851 (2009).

38. Gowd, S. S. \& Govil, P. K. Distribution of heavy metals in surface water of Ranipet industrial area in Tamil Nadu, India. Environ. Monit. Assess. 136, 197-207 (2008).

39. Bishnoi, N. R., Bajaj, M., Sharma, N. \& Gupta, A. Adsorption of $\mathrm{Cr}$ (VI) on activated rice husk carbon and activated alumina. Bioresour. Technol. 91, 305-307 (2004).

40. Parmar, M. \& Thakur, L. S. Heavy metal Cu, Ni and Zn: toxicity, health hazards and their removal techniques by low cost adsorbents: a short overview. Int. J. Plant Anim. Environ. Sci. 3, 2231-4490 (2013).

41. Oliveira, E. A., Montanher, S. F., Andrade, A. D., Nobrega, J. A. \& Rollemberg, M. C. Equilibrium studies for the sorption of chromium and nickel from aqueous solutions using raw rice bran. Process Biochem. 40, 3485-3490 (2005).

42. Shukla, S. S., Yu, L. J., Dorris, K. L. \& Shukla, A. Removal of nickel from aqueous solutions by sawdust. J. Hazard. Mater. 121, 243-246 (2005).

43. Aliabadi, M., Morshedzadeh, K. \& Soheyli, H. Removal of hexavalent chromium from aqueous solution by lignocellulosic solid wastes. Int. J. Environ. Sci. Technol. 3, 321-325 (2006)

44. Ajmal, M., Rao, R. A., Ahmad, R. \& Ahmad, J. Adsorption studies on Citrus reticulata (fruit peel of orange): removal and recovery of Ni (II) from electroplating wastewater. J. Hazard. Mater. 79, 117-131 (2000)

45. Babel, S. \& Kurniawan, T. A. Cr (VI) removal from synthetic wastewater using coconut shell charcoal and commercial activated carbon modified with oxidizing agents and/or chitosan. Chemosphere 54, 951-967 (2004).
46. Tang, P. L., Lee, C. K., Low, K. S. \& Zainal, Z. Sorption of $\mathrm{Cr}$ (VI) and Cu (II) in aqueous solution by ethylenediamine modified rice hull. Environ. Technol. 24, 1243-1251 (2003)

47. Zouboulis, A. I. \& Kydros, K. A. Use of red mud for toxic metals removal: the case of nickel. J. Chem. Technol. Biotechnol. 58, 95-101 (1993).

48. Daneshvar, N., Salari, D. \& Aber, S. Chromium adsorption and $\mathrm{Cr}(\mathrm{VI})$ reduction to trivalent chromium in aqueous solutions by soya cake. J. Hazard. Mater. 94, 49-61 (2002).

49. Mor, S., Ravindra, K. \& Bishnoi, N. R. Adsorption of chromium from aqueous solution by activated alumina and activated charcoal. Bioresour. Technol. 98, 954-957 (2007)

50. Nameni, M., Moghadam, M. A. \& Arami, M. Adsorption of hexavalent chromium from aqueous solutions by wheat bran. Int. J. Environ. Sci. Technol. 5, 161-168 (2008).

51. Argun, M. E., Dursun, S., Ozdemir, C. \& Karatas, M. Heavy metal adsorption by modified oak sawdust: thermodynamics and kinetics. J. Hazard. Mater. 141, 77-85 (2007).

52. Santiago, I., Worland, V. P., Cazares, E. R. \& Cadena, F. Adsorption of hexavalent chromium onto tailored zeolites. 47th Purdue Industrial Waste Conference Proc. 44, 669-710 (Lewis Publishers, Inc, Chelsea, MI, USA, 1993).

53. Demirbas, E., Kobya, M., Senturk, E. \& Ozkan, T. Adsorption kinetics for the removal of chromium (VI) from aqueous solutions on the activated carbons prepared from agricultural wastes. Water SA 30, 533-539 (2004).

54. Li, F. T., Yang, H., Zhao, Y. \& Xu, R. Novel modified pectin for heavy metal adsorption. Chin. Chem. Lett. 18, 325-328 (2007).

55. Gheju, M., lovi, A. \& Balcu, I. Hexavalent chromium reduction with scrap iron in continuous-flow system: Part 1: effect of feed solution pH. J. Hazard. Mater. 153, 655-662 (2008)

56. Li, Y., Jin, Z., Li, T. \& Xiu, Z. One-step synthesis and characterization of core-shell Fe@SiO2 nanocomposite for Cr (VI) reduction. Sci. Total Environ. 421, 260-266 (2012).

57. Pehlivan, E. \& Altun, T. The study of various parameters affecting the ion exchange of $\mathrm{Cu} 2+, \mathrm{Zn} 2+, \mathrm{Ni} 2+, \mathrm{Cd} 2+$, and $\mathrm{Pb} 2+$ from aqueous solution on Dowex 50W synthetic resin. J. Hazard. Mater. 134, 149-156 (2006).

58. Dakiky, M., Khamis, M., Manassra, A. \& Mer'eb, M. Selective adsorption of chromium (VI) in industrial wastewater using low-cost abundantly available adsorbents. Adv. Environ. Res. 6, 533-540 (2002).

59. Meunier, N. et al. Comparison between electrocoagulation and chemical precipitation for metals removal from acidic soil leachate. J. Hazard. Mater. 137, 581-590 (2006)

Open Access This article is licensed under a Creative Commons Attribution 4.0 International License, which permits use, sharing, adaptation, distribution and reproduction in any medium or format, as long as you give appropriate credit to the original author(s) and the source, provide a link to the Creative Commons license, and indicate if changes were made. The images or other third party material in this article are included in the article's Creative Commons license, unless indicated otherwise in a credit line to the material. If material is not included in the article's Creative Commons license and your intended use is not permitted by statutory regulation or exceeds the permitted use, you will need to obtain permission directly from the copyright holder. To view a copy of this license, visit http://creativecommons. org/licenses/by/4.0/.

(c) The Author(s) 2018 